\title{
Physical and chemical analyzis of chardonnay wine with different periods of skin contact
}

\author{
Pedro Pohlmann Giriboni ${ }^{1}$, Angélico Xavier ${ }^{1}$, Valeska Roque ${ }^{2}$, Graziani Vargas $^{1}$, Filipe Souza ${ }^{1}$, and Vagner Brasil Costa ${ }^{1}$ \\ ${ }^{1}$ Universidade Federal do Pampa - UNIPAMPA Dom Pedrito, Brazil \\ ${ }^{2}$ Universidade Federal do Rio Grande do Sul - UFRGS, Brazil
}

\begin{abstract}
Aromatic precursors are precisely in the skin of grapes and nearby cells, and therefore there is a greater expression of the varietal aromas and aromatic precursors when the wine passes through this skin contact, as well as changes in product color. The aim of this study was to evaluate the physical and chemical characteristics of Chardonnay wine that has gone through different periods of skin contact. Chardonnay grapes, grown in vineyards located in the town of Bagé, in Campanha Gaúcha, were de-stemmed, crushed and a sulfur dioxide $\left(50 \mathrm{mg} / \mathrm{L}^{-1}\right)$ was addeded. The experimental design was a $4 \times 3$ factorial of 4 treatments with 3 repetitions: T1, the wine obtained directly from pressing machine; T2, skin contact for 2 days; T3, skin contact for 4 days and T4, skin contact for 6 days. After the end of malolactic fermentation wines went under $-2^{\circ} \mathrm{C}$ for the tartaric stabilization. There were analyzed the variables alcohol, total acidity, volatile acidity, total polyphenols, glycerol, gluconic acid and 420, 520 and 620 colors by infrared spectroscopy method by Fourier transform and the means were compared by 5\% Tukey test. There was a significant differencein variables alcohol, volatile acidit, glucanic acid and color index of $420 \mathrm{~nm}$ (yellow).
\end{abstract}

\section{Introduction}

Viticulture in Campanha Gaucha, Rio Grande do Sul, Brazil,has expanded in the last decade and is currently the second largest producer of fine wines in this country. The region, situated in the parallel $31^{\circ}$ South, is characterized by hot summers and with good sunlight, good thermal amplitude and favorable soil for quality viticulture (Giovannini \& Manfroi, 2009). In addition, technological advances and the correct management in the vineyards allows the obtainance of high quality products that can compete in the domestic market. Currently, there re produced in the region red, white and rosé wines.

Still not widely produced in Brazil, a new product type that have received attention are the macerated along the alcoholic fermentation white wines. Its production process differs from white wines mainly by the existence of a time of maceration of the skins of grapes with wine / wine during alcoholic fermentation. This process phenolic compounds in wines and improves the beneficial antioxidant effect on human health related to these molecules (Ruzic, Skerget \& Knez, 2001; Darias-Martín et al., 2000).

The aroma of wine depends on several factors, such as the development of the plant in the vineyard, oenological practices, farming, the usage of determined yeast in wine making, among others, but white wines pre-fermentation maceration has shown to be important for the increase in floral and fruity aromas (Selli, 2006).

Furthermore, Ribéreau-Gayon et al. (2003) stated that varietal aromas and other aromatic precursors are precisely located in the skin of grapes and in nearby cells, leading to greater intensity in wines made using this technique. This may explain the higher aromatic concentrations in orange wines, even if they are produced with neutral grapes.

There is little literature about this winemaking technique in Brazil, which leaves open space for research to determine the best cultivars to be used, the optimal production technology and the correct steeping time for the product to be interesting from a consumer point of view.

The objective of this study was to determine the optimal time of contact between wine and skin and evaluate its physic and chemical characteristics.

\section{Methodology}

Chardonnay grapes, grown in vineyards located in the tpemof Bage, in campanha Gaucha, were harvested at full maturity, on the morning of 11/2/2016, and transported in plastic boxes to Universidade Federal doPampa, where they were kept in cold storage under the temperature of $5^{\circ} \mathrm{C}$ for 24 hours.

The grapes were separated in boxes and labeled in accordance with the treatment to which correspond, and $27 \mathrm{~kg}$ were used per treatment. The grapes were destemmed, crushed and added sulfur dioxide $\left(50 \mathrm{mg} / \mathrm{L}^{-1}\right)$. It was inoculated $30 \mathrm{~g} / \mathrm{hL}^{-1}$ of Saccharomyces cerevisiae, $30 \mathrm{~g} \mathrm{hL}^{-1}$. The treatments were packed in glass bottles with $14 \mathrm{~L}$ capacity. Treatment 1 (T1) is obtained by direct pressing wine; T2, wine with maceration for 2 days; T3, maceration for 4 days and T4, maceration for six 6 days. Fermentations took place under controlled temperature $\left(20^{\circ} \mathrm{C}\right)$. Final pressing was performed in manual pressing equipment. Treatments were replicated three times, a total of 12 glass bottles with 
Table 1. Análises Físico-químicas de vinhos Chardonnay com diferentes tempos de contato com as cascas. Dom Pedrito, RS, 2016.

\begin{tabular}{lcccc}
\hline Variáveis/Tratamentos & T1 & T2 & T3 & T4 \\
\hline Álcool & $12,79^{\mathrm{a}}$ & $12,41^{\mathrm{ab}}$ & $12,16^{\mathrm{bc}}$ & $11,97^{\mathrm{c}}$ \\
Acidez Total & $5,76^{\mathrm{a}}$ & $4,90^{\mathrm{a}}$ & $5,20^{\mathrm{a}}$ & $5,33^{\mathrm{a}}$ \\
Acidez Volátil & $0,36^{\mathrm{b}}$ & $0,50^{\mathrm{a}}$ & $0,53^{\mathrm{a}}$ & $0,57^{\mathrm{a}}$ \\
IPT & $16,10^{\mathrm{a}}$ & $18,50^{\mathrm{a}}$ & $19,83^{\mathrm{a}}$ & $17,70^{\mathrm{a}}$ \\
Glicerol & $7,80^{\mathrm{a}}$ & $7,27^{\mathrm{a}}$ & $7,43^{\mathrm{a}}$ & $6,97^{\mathrm{a}}$ \\
Ác. Glucânico & $0,03^{\mathrm{b}}$ & $0,13^{\mathrm{ab}}$ & $0,29^{\mathrm{a}}$ & $0,30^{\mathrm{a}}$ \\
420 & $0,038^{\mathrm{b}}$ & $0,070^{\mathrm{ab}}$ & $0,082^{\mathrm{a}}$ & $0,077^{\mathrm{ab}}$ \\
520 & $0,002^{\mathrm{a}}$ & $0,014^{\mathrm{a}}$ & $0,021^{\mathrm{a}}$ & $0,020^{\mathrm{a}}$ \\
620 & $0,002^{\mathrm{a}}$ & $0,012^{\mathrm{a}}$ & $0,017^{\mathrm{a}}$ & $0,016^{\mathrm{a}}$ \\
\hline
\end{tabular}

* Resultados seguidos de mesma letra na linha não diferiram entre si ao nível de $5 \%$ de probabilidade utilizando o teste de Tukey;

** Resultados seguidos de diferentes letras na linhas, diferiram entre a nível de 5\% de probabilidade utilizando o teste de Tukey.

capacity of 14L-1.After this. repetitions were racked for bottles of $4,5 \mathrm{~L}^{-1}$. At the end of the alcoholic fermentation, there was occurrence of malolactic fermentation, already underway.

After the end of malolactic fermentation the wines were racked and taken to the cold storage under negative temperatures to pass through tartaric stabilization. Samples were analyzed in Winescam FOSS FTIR by evaluating the following variables: volatile acid, gluconic acid, color indices $(420,520$ and $620 \mathrm{~nm})$, glycerol, total polyphenol content, total acidity and alcohol.

\section{Results and discussion}

In the variable alcohol, T1 statistically different compared to $\mathrm{T} 3$ and $\mathrm{T} 4$, showing the highest value of 12.79 v.v, It is noticeable a decrease in alcohol content according to the increased contact time with skin, probably related to a possible oxidation of the alcohol. Cabaroglu et al., (1997) shows that juice macerated white cultivars during fermentation are more alcoholic and have higher volatile acidity, in addition to having greater quantity of phenols and other molecules In this case, this work just confirms the higher concentration of volatile acidity, since $\mathrm{T} 1$ differed from the other samples in this variable, having the lowest value, with $0.36 \mathrm{~g} \cdot \mathrm{L}^{-1}$. This may be related to the lesser amount of alcohol, recently discussed.

In the variable glucanic acid, $\mathrm{T} 1$ showed the lowest concentration $\left(0: 03 \mathrm{~g} \cdot \mathrm{L}^{-1}\right)$ and $\mathrm{T} 4$ the higher $\left(0.30 \mathrm{~g} \cdot \mathrm{L}^{-1}\right)$, being statistically different. This acid is related to poor preservation of wine over time and appears to be associated with the maceration period.
The variable glycerol did not differ statistically, which can be explained by the fact that all wines get in contact with the lees for the same period;

It was expected statistical differences in the variable Index of Total Polyphenols, which in fact is reported by Arnold \& Noble (1979). This result was not found despite the prolonged contact with the skins for a white wine. A larger maceration for more days would probably increase the ITP.

As for color, the T3 differed from $\mathrm{T}$, showing more intense yellow color (A420). The other shades, responsible for the red and blue colorations showed no statistical difference, as were expected since chardonnayis a white grape cultivr.

\section{Conclusions}

According to the results (Table 1), there was a significant differencein variables alcohol, volatile acidit, glucanic acid and color index of $420 \mathrm{~nm}$ (yellow). For othervariables analyzed, there is no significant difference between treatments. Other tests should be performe, particularly to discuss the flavor profile of these wines and confirm the results herein. Obtaining quality wines boost the sector, allowing the use of the white grape skin in the production of a second product.

\section{References}

Arnold, R. A., Noble, A. C., 1979: Effect of pomace contact on the flavor of Chardonnay wine. Amer. J. Enol . Viticult . 30, 179-181

Cabaroglu, T., Canbas, A., Baumes, R., Bayonove, C., Lepoutre, J.P., Günata, Z. Aroma composition of a White wine of Vitis vinifera L. cv. Emir as affected by skin contact. Journal of Food and Science. v 62. n 04. p 180-183, 1997

Darias-Martín, J., Rodríguez, O., Díaz, E., Lamuela Raventós, R. M. Effect of skin contact on the antioxidant phenolics in white wine. Food Chemistry. V 71. Issue 4. p 483-487, 2000

Giovanini, E., Manfroi, V. Viticultura e Enologia: Elaboração de grandes vinhos nos terroirs do brasileiros. IFRS, Bento Gonçalves, 2009

Ruzic, I., Skerget, M., Knez, K., Phenolic content and antioxidant potential of macerated white wines. Europeand food research and technology. V 233. issue 3. p 465-472, 2011

Selli, S., Canbas, A., Cabaroglu, T., Erten, H., Lepoutre, J.P., Gunata, Z. Effect of skin contact on the free and bound aroma compounds of the white wine of Vitis vinifera cv. Narince. Food Control. V 17, p 75-82, 2006 